\title{
Defense Access to State-Funded DNA Experts: Considerations of Due Process
}

\author{
Jay A. Zollinger $\dagger$
}

Most state courts now accept DNA fingerprinting technology as a valid and useful forensic tool. However, courts confronted with requests from indigent defendants for funds to hire a DNA expert or to retest evidentiary samples have reached inconsistent conclusions about the due process implications of such a request. While some courts have concluded that every criminal defendant confronted with DNA evidence is entitled to the services of an expert, others have relied on a variety of grounds to reject requests for state-funded assistance. This Comment attempts to add to the debate by carefully examining the role a DNA expert could play in a criminal trial and the extent to which DNA evidence is affected by uncertainty and ambiguity. This analysis leads to the conclusion that every defendant confronted with DNA evidence has a due process right to receive the funds needed to hire an independent DNA expert.

\section{INTRODUCTION}

For almost a decade now, the scientific and legal communities have been debating the legitimacy of DNA fingerprinting technology as a forensic tool. ${ }^{1}$ To date, the primary focus of this debate has been the admissibility of DNA evidence in criminal cases. ${ }^{2}$ As time has passed, and people have become more familiar with DNA technology, most

Copyright $\odot 1997$ California Law Review, Inc.

$\dot{i}$ Associate, Perkins Coie, Portland, Oregon. J.D. 1997, Boalt Hall School of Law, University of California at Berkeley. I must thank Professor Eleanor Swift, without whose help 1 could not have written this Comment. More than anyone eise, however, I must thank Kim, Cole, and Jade, without whose patient support I could not do anything.

1. See NRC Report in Forensic Science, Board on Biology, Commission on life Sciences, National Research Council, DNa Technology in Forensic Science 28-32, 132142 (1992) [hereinafter NRC REPORT] (identifying some of the questions and criticisms that have been raised about the forensic use of DNA technology and providing a summary of judicial reactions to the introduction of DNA technology to the criminal justice system).

2. See generally id. at $132-42$ (providing a history of how courts have dealt with the admissibility questions surrounding DNA evidence). 
courts, ${ }^{3}$ legislatures ${ }^{4}$ and scientists ${ }^{5}$ have decided the issue in favor of admissibility. However, this decision resolves only the first question in the forensic DNA debate- it raises many others about how the courts should administer and monitor the use of DNA technology in the courtroom. One of the most important of these questions is whether the Constitution requires a state to provide indigent defendants with the tools needed to attack DNA evidence the state proffers against them. Once the admissibility barrier is removed, prosecutors will almost certainly rely on DNA fingerprinting technologies more frequently. As this happens, more and more defendants will seek assistance in retesting, interpreting, or attacking the prosecution's evidence and will flood the courts with requests that the state provide the funds needed for assistance.

State courts that have already considered such requests have reached inconsistent conclusions. Some have concluded that the risk of error if a DNA expert is not provided is significant enough that the state must provide an expert to every defendant confronted with DNA

3. See, e.g., Ex parte Perry, 586 So. 2 d 242 (Ala. 1991); Prater v. Arkansas, 820 S.W.2d 429 (Ark. 1991); Fishback v. Colorado, 851 P.2d 884 (Colo. 1993); Johnson v. Georgia, 461 S.E.2d 209 (Ga. 1995); Hawaii v. Montalbo, 828 P.2d 1274 (Haw. 1992); Idaho v. Faught, 908 P.2d 566 (ldaho 1995); Davidson v. Indiana, 580 N.E.2d 238 (Ind. 1991); lowa v. Brown, 470 N.IV.2d 30 (lowa 1991); Smith v. Deppish, 807 P.2d 144 (Kan. 1991); Mitchell v. Kentucky, 908 S.W.2d 100 (Ky. 1995); Louisiana v. Charles, 617 So. 2d 895 (La. 1993); Massachusetts v. Lanigan, 641 N.E.2d 1342 (Mass. 1994); Minnesota v. Bloom, 516 N.W.2d 159 (Minn. 1994); Polk v. Mississippi, 612 So. 2d 381 (Miss. 1992); Missouri v. Davis, 814 S.IV.2d 593 (Mo. 1991); Montana v. Weeks, 891 P.2d 477 (Mont. 1995); New Mexico v. Duran, 881 P.2d 48 (N.M. 1994); New York v. Welsey, 633 N.E.2d 451 (N.Y. 1994); North Carolina v. Pennington, 393 S.E.2d 847 (N.C. 1990); Ohio v. Pierce, 597 N.E.2d 107 (Ohio 1992); Oregon v. Herzog, 924 P.2d 817 (Or. 1996); Pennsylvania v. Crews, 640 A.2d 395 (Pa. 1994); South Carolina v. Ford, 392 S.E.2d 781 (S.C. 1990); South Dakota v. Wimberly, 467 N.W.2d 499 (S.D. 1991); Vermont v. Passino, 640 A.2d 547 (Vt. 1994); Spencer v. Virginia, 384 S.E.2d 785 (Va. 1989); West Virginia v. Woodall, 385 S.E.2d 253 (W. Va. 1989); Springfield v. Wyoming, 860 P.2d 435 (Wyo. 1993); see also NRC RePoRt 11, National. Research CouncIL, The Evaluation OF FORENSIC DNA EVIDENCE, 205-09, app. at 6A (1996) [hereinafter NRC REPORT II] (listing state supreme court decisions on the admissibility of DNA evidence); 2 PAUL C. GIANNELL.I \& EDWARD J. IMWINKELRIED, SCIENTIFIC EVIDENCE 6 (2d ed. Supp. 1994) (noting federal court decisions that have upheld the admissibility of DNA evidence when the National Research Council's ("NRC") recommendations for statistical calculations are followed).

4. See, e.g. Ala. Code $\S 36-18-30$ (1975); Alaska Stat. $\$ 12.45 .035$ (Michie 1995); ConN. Gen. Stat. ANN. § 54-86k (West 1994); Del. Code ANN. tit. $11, \S 3515$ (1974); lNd. Code AnN. 35-37-4-13 (West 1996); LA. Rev. Stat. ANN. § 15:441.1 (West 1989); Md. Code ANN., CTs. \& Jud. Proc. § 10-915 (1991); Minn. STAT. ANN. § 634.25 (West 1997); TENN. CODE ANN. \$ 24-7-117 (1996); VA. CODE ANN. $\$$ 19.2-270.5 (Michie 1995) (each declaring DNA evidence admissible in criminal trials).

5. See, e.g., Eric S. Lander \& Bruce Budowle, DNA Fingerprinting Dispute Laid to Rest, 371 NATURE 735 (1994), in which the authors declared that they had recently discussed the current state of DNA typing, and could identify no problem that should prevent the full use of DNA evidence in any court. According to these scientists, "The DNA fingerprinting wars are over." Id. This declaration was especially important for Lander, who had been "an early and vigorous critic of the lack of scientific standards" and the rush to use DNA evidence in criminal trials. 
evidence. ${ }^{6}$ At least one, however, has come to the opposite conclusion. ${ }^{7}$ Most courts have avoided the due process issue altogether by holding that the defendant before them had failed to demonstrate any reasonable need for an expert. ${ }^{8}$ In light of these inconsistent responses to such an important question, this Comment examines the due process implications of a defendant's request for a DNA expert.

A defendant's request for state-funded assistance in a DNA case must be analyzed in terms of the specific problems that can affect the forensic use of DNA technology. ${ }^{9}$ This Comment assesses both the role a defense expert would play in recognizing and addressing these problems and the various uncertainties and ambiguities that may affect every forensic DNA test. Based upon this assessment, the Comment concludes that whenever the prosecution relies on DNA evidence the criminal defendant enjoys a right, founded in the Constitution's guarantee of due process, to obtain the services of a DNA expert. By itself, the prosecution's introduction of DNA evidence against a defendant is sufficient to establish the threshold level of need that triggers a due process analysis of the request for an expert. The balance of the factors involved in this analysis suggests that every defendant should receive an independent

6. See, e.g., Dubose v. Alabama, 662 So. 2d 1189, 1197 (Ala. 1995); Polk, 612 So. 2d at 393.

7. See Harrison v. Indiana, 644 N.E.2d 1243, 1252-53 (Ind. 1995); see also West Virginia v. Derr, 451 S.E.2d 731, 749 n.23 (W. Va. 1994) (dismissing without discussion defendant's claim of error in denial of motion for DNA expert).

8. See, e.g., Cade v. Florida, 658 So. 2d 550, 554-55 (Fla. Dist. Ct. App. 1995); Michigan v. Leonard, 224 Mich. App. 569 (1997); Coleman v. Mississippi, 697 So. 2d 777 (Miss. 1997); North Carolina v. Mills, 420 S.E.2d 114, 118-19 (N.C. 1992); Tennessee v. Edwards, 868 S.W.2d 682, 697 98 (Tenn. Crim. App. 1993); Husske v. Virginia, 476 S.E.2d 920 (Va. 1996); see also Norton v. Texas, 930 S.W.2d 101 (Tex. App. 1996) (holding that defendant, who did receive a DNA expert, had not demonstrated that his requested DNA test would be useful); Taylor v. Texas, 939 S.W.2d 148 (Tex. Crim. App. 1996) (reversing a lower court's decision for failing to determine whether the defendant had shown that a DNA expert would be a "significant factor" at trial).

9. This Comment considers one particular kind of DNA fingerprinting: restriction fragment length polymorphism ("RFLP") analysis. Recently, a second kind of test, polymerase chain reaction ("PCR") testing, has become widely used in criminal trials. See NRC REPORT, supra note 1, at 40-44. There is also a possibility that both RFLP and PCR analysis will eventually be replaced by other, less problematic techniques. See Alec J. Jeffreys et al., Minisatellite Repeat Coding as a Digital Approach to DNA Typing, 354 NATURE 204 (1991). For the moment, however, RFLP technology is the bestestablished form of forensic DNA testing and probably the most common. See Judith A. McKenna et al., Reference Guide on Forensic DNA Evidence, in Reference Manual on Scientific Evidence 273, 277 (1994).

Because RFLP is currently so common, most of the literature evaluating the validity and reliability of DNA testing has focused on RFLP technology. While the analysis undertaken by this Comment is directed at the RFLP process, much of what 1 say here may also apply to other forms of DNA analysis. William Thompson suggests that many of the problems involved in RFLP testing are actually more pronounced in PCR testing. See Electronic Mail Message from William C. Thompson, Professor, Department of Criminology, Law \& Society, School of Social Ecology, University of California, Irvine (Mar. 7, 1996) (on file with the author). Because RFLP testing is likely to remain a common practice for some time, the analysis of the possible impact of an expert in cases dealing with RFLP will be of continuing importance. 
expert to review the DNA evidence proffered by the prosecution. By contrast, retesting DNA that the prosecution has examined provides limited additional utility in identifying the sorts of problems that may affect the prosecution's DNA tests. In light of this limited utility, this Comment concludes that courts should grant a request for funds to perform a second series of tests only where the defendant's DNA expert has demonstrated exactly how retesting would be useful.

I

The Legal Background

A. The Demands of Due Process: Mathews v. Eldridge

The analysis of whether a defendant has a right to assistance in a DNA case must begin with Mathews v. Eldridge, ${ }^{10}$ in which the Supreme Court first articulated the test courts use to determine the meaning of the Due Process Clause in a particular case. At issue in Mathews was whether the Constitution requires an evidentiary hearing prior to the termination of Social Security disability benefits. In deciding that issue, the Court declared that the specific dictates of the Due Process Clause require consideration of three distinct factors:

First, the private interest that will be affected by the official action; second, the risk of an erroneous deprivation of such interest through the procedures used, and the probable value, if any, of additional or substitute procedural safeguards; and finally, the Government's interest, including the function involved and the fiscal and administrative burdens that the additional or substitute procedural requirement would entail."

\section{B. The Mathews Test Applied to Expert Assistance: Ake v. Oklahoma}

By itself, Mathews offers little guidance to a court that must identify and evaluate the different interests involved in a request for assistance in a DNA case. But in Ake v. Oklahoma, ${ }^{12}$ the Supreme Court applied the Mathews test to the question of whether a state must provide a defendant with the services of an independent psychiatric expert. The services of DNA experts are similar in many ways to those provided by psychiatric experts. ${ }^{13}$ By applying the Ake Court's analysis to the realities of DNA testing, it is possible to identify more accurately the private and state interests involved in a request for a DNA expert. This

\footnotetext{
10. 424 U.S. 319 (1976).

11. Id. at 335 .

12. 470 U.S. 68 (1985).

13. See infra Part IV.
} 
comparison also facilitates a determination of the weight that should be given to each of these interests.

The Ake Court identified the task before it as one of deciding "whether and under what conditions, the participation of a psychiatrist is important enough to the preparation of a defense to require the State to provide an indigent defendant with access to competent psychiatric assistance in preparing the defense."14 To do this, the Court applied the Mathews test, which it characterized as one of determining the balance between: 1) "the private interest that will be affected by the action of the State," 2) "the governmental interest that will be affected if the safeguard is to be provided," and 3) "the probable value of the additional or substitute procedural safeguards that are sought, and the risk of an erroneous deprivation of the affected interest if those safeguards are not provided."15

The Ake Court found the private interest involved in a request for the assistance of a psychiatric expert extremely compelling. In fact, the private interest involved in a criminal proceeding, where an individual's life or liberty is at stake, is so "uniquely compelling" that the Court held its importance to be obvious: "The interest of the individual in the outcome of the State's effort to overcome the presumption of innocence is obvious and weighs heavily in our analysis."16

By contrast, the Court found that the state's interest in such a case is limited. It rejected Oklahoma's claim that recognizing a constitutional right to expert services under the facts presented in Ake would impose a "staggering burden" on the state. ${ }^{17}$ In criminal cases, observed the Court, the state has no conceivable interest other than the financial burden created by funding the provision of expert wituesses. Because the state's interest in prevailing at trial "is necessarily tempered by its interest in the fair and accurate adjudication of criminal cases," the state's economic interest is the only possible grounds for denying the requested funding. ${ }^{18}$ In some situations, this burden may be so great that it is compelling. The burden is not compelling, however, when the state's obligation is limited to providing each indigent defendant with the services of one psychiatrist and the defendant demonstrates that his sanity will be an issue during the trial. ${ }^{19}$

14. Ake, 470 U.S. at 77.

15. Id. (citing Little v. Streater, 452 U.S. 1, 6 (1981) and Mathews v. Eldridge, 424 U.S. 319, 335 (1976)).

16. Id.

17. Id.

18. Id. at 79.

19. The Court notes that the right to state-funded psychiatric evaluation is limited to the appointment of a single psychiatrist. See id. 
The bulk of the Ake decision concerns the risk of an inaccurate resolution of the issue of sanity in the absence of a defense expert and the probable value of the services of a psychiatrist. The Court's discussion of this final element of the Mathews analysis raises two themes that prove central to the consideration of a request for assistance in a DNA case. In order to determine the value of an expert and the risk of inaccurate fact finding if one is not provided, the Ake Court undertook a detailed analysis of: 1) the role that a psychiatric expert might play in a criminal trial; and 2) the degree to which psychiatry is an inexact science.

The Court described the role of a defense expert in a case dealing with psychiatric evidence as one of "investigation, interpretation, and testimony." 20 Important aspects of this process include gathering facts through examinations and interviews, analyzing information and drawing plausible conclusions about the defendant's mental condition, translating the technical language of medical reports into language that will assist the trier of fact, and knowing "the probative questions to ask of the opposing party's psychiatrists and how to interpret their answers."21 Throughout all of this, the psychiatrist's primary role is to "assist lay jurors, who generally have no training in psychiatric matters, to make a sensible and educated determination about the mental condition of the defendant at the time of the offense."22 Based upon this assessment of what a psychiatrist does, the Court noted that the impact on a criminal trial of an independent psychiatric expert will be great, especially given the potential for disagreement among different psychiatric experts. ${ }^{23}$

The Court's assessment of the uncertainties involved in psychiatry bolsters this conclusion. The Court noted that psychiatry is not an exact science-there is often "no single, accurate psychiatric conclusion on legal sanity in a given case." 24 Because of the high degree of uncertainty involved in psychiatry, the opportunity for a defendant to have his own expert evaluate the opposition's evidence and to testify about her own conclusions will necessarily have an impact on a jury charged with making a determination of sanity: "When jurors [must determine facts] about issues that inevitably are complex and foreign, the testimony of psychiatrists can be crucial and 'a virtual necessity if an

\footnotetext{
20. Id. at 80 .

21. Id.

22. Id. at 81 .

23. See id.

24. Id.
} 
insanity plea is to have any chance of success."'25 The Ake Court concluded that denying access to a psychiatrist would create a great risk of inaccurate resolution of the question of a defendant's sanity. ${ }^{26}$

Weighing the interests of the individual and the state against the value of the requested services and the risk of inaccurate fact finding if the services are unavailable, the Ake Court concluded that the defendant's interest in access to the services of a psychiatric expert outweighs the state's interest in not providing the requested services. "In such a circumstance, where the potential accuracy of the jury's determination is so dramatically enhanced, and where the interests of the individual and the State in an accurate proceeding are substantial, the State's interest in its fisc must yield."27 Therefore, held the Court, a state must "assure the defendant access to a competent psychiatrist who will conduct an appropriate examination and assist in the evaluation, preparation, and presentation of the defense."28

\section{An Additional Hurdle: Caldwell v. Mississippi}

Long before the Ake Court's observations concerning psychiatry were ever analogized to a request for a DNA expert, the Supreme Court added one further layer to its application of the Mathews due process test to a request for expert assistance. In Caldwell $v$. Mississippi, ${ }^{29}$ decided the same term as Ake, a defendant who was provided with a psychiatric expert was denied the services of a criminal investigator, a fingerprint expert, and a ballistics expert..$^{30}$ In a footnote addressing these rejected requests, the Court upheld the Mississippi Supreme Court's holding, which had justified the denial of funding on the grounds that the defendant's requests "were accompanied by no showing as to their reasonableness." 31 Now, before applying the Mathews test, a court must first determine whether the defendant has adequately demonstrated that his request for expert assistance is reasonable. "Reasonable," in this context, means that a defendant must establish that the requested services would be important to his case-that there exists a "reasonable probability both that an expert would be of

25. Id. (quoting Martin R. Gardner, The Myth of the Impartial Psychiatric Expert-Some Comments Concerning Criminal Responsibility and the Decline of the Age of Therapy, 2 LAW \& PsYchol. REV. 99, 113-14 (1976)).

26. See id. at 82 .

27. Id. at 83 (footnote omitted).

28. Id.

29. 472 U.S. 320 (1985).

30. See id. at 323 n.1.

31. Id. The Court offers the defendant's statement that a ballistics expert "would be of great necessarius [sic] witness" as an example of his failure to demonstrate need. Id. (quoting Caldwell v. Mississippi, 443 So. 2d 806, 812 (Miss. 1983)). 
assistance to the defense and that denial of expert assistance would result in a fundamentally unfair trial." 32

This final hurdle completes our picture of the analytical framework that any court must follow when confronted with a request for a DNA expert or a second series of tests. First, under Caldwell, a court must determine whether a defendant's request for expert assistance is reasonable. If it is, then the court must apply the Mathews balancing test, turning to $A k e$ for guidance in understanding and evaluating the different interests involved.

\section{The Test Applied in the Lower Courts}

To date, state courts have only considered a defendant's request for assistance in a DNA case in a handful of published opinions. ${ }^{33}$ These courts have reached different conclusions concerning the issues involved in such a request. This confusion stems, in large part, from different responses to the themes of uncertainty and of the role of an expert-the same two themes that were central to the Ake Court's analysis of the need for a psychiatrist. Specifically, state courts have differed over the role that a DNA expert could play in a criminal case and over the level of uncertainty that affects the forensic use of DNA technology. This disagreement has led, in turn, to different conclusions concerning both the reasonableness of a defendant's request for assistance and concerning whether due process demands that a defendant have access to state-funded assistance.

\section{The Role of the Expert}

The different state-court responses to requests for a DNA expert reveal a variety of understandings of the role such an expert would play in a criminal trial. Some courts have accepted the argument that, because a DNA expert gathers facts, analyzes information, draws plausible conclusions, and assists the jury, any defendant confronted with DNA evidence should receive the assistance of an expert. Other courts, apparently assuming that a DNA expert can do no more than passively inform or educate a defense attorney, have rejected requests for an expert as unreasonable.

Mississippi and Alabama have concluded that due process requires a state to provide a DNA expert to every indigent defendant. In Polk $v$. Mississippi ${ }^{34}$ the Mississippi Supreme Court decided that DNA evidence is admissible in a criminal trial. In an appendix attached to its decision concerning admissibility, the court also expressed its opinion that all

\footnotetext{
32. Moore v. Kemp, 809 F.2d 702, 712 (11th Cir. 1987) (footnote omitted).

33. See supra notes 6-8 and accompanying text.

34. 612 So. $2 d 381$ (Miss. 1992).
} 
defendants confronted with DNA evidence have a due process right to have an independent expert evaluate that evidence. ${ }^{35}$ In support of this conclusion, the Polk court argued that, like a psychiatrist, DNA experts gather facts, analyze data, draw conclusions, know the probative questions to ask of the opposing party's expert, and can translate complex and technical language into language a jury can understand. ${ }^{36}$ Based upon these observations, the court concluded that it is "imperative that no defendant have [DNA] evidence admitted against him without the benefit of an independent expert witness to evaluate the data on his behalf."

In Dubose v. Alabama, ${ }^{38}$ the Supreme Court of Alabama emphasized a similar understanding of the role of a DNA expert when it held that the state trial court had wrongfully denied a criminal defendant's request for assistance. The Dubose court based its holding on the difficulties involved in understanding DNA evidence and in presenting such evidence to a jury. The court noted that defense attorneys are generally ill-equipped to address the complexities of DNA evidence, ${ }^{39}$ that the prosecution experts interpreting such evidence often quote "extraordinarily high numbers," 40 and that, as a result, the jury may give DNA evidence inappropriate weight in its decision making process. ${ }^{41}$ Given these difficulties, the court concluded that a DNA expert would play a role similar to the role of a psychiatric expert as described by the Ake Court-the expert would evaluate the prosecution's evidence, draw appropriate conclusions, and assist the defense attorney in presenting the evidence to a jury. ${ }^{42}$ Based on its observation that a DNA expert is important to the defense, the Dubose opinion holds that "a n indigent defendant against whom DNA evidence will be offered must have access to a DNA expert to assist in his defense." $" 43$

35. See id. at 393-94. Even though the primary issue in Polk was the admissibility of DNA evidence, the court took advantage of the opportunity before it to attach an appendix to its opinion that addresses the issue of defense access to the services of DNA experts. See id. The court identifies the purpose of this appendix as establishing "guidelines" for the bench and bar concerning the use of DNA technology in the courtroom. Id. at 393.

36. See id. at 393-94 (quoting Ake v. Oklahoma, 470 U.S. 68, 80 (1985)).

37. Id. at 393.

38. 662 So. 2 d 1189 (Ala. 1995).

39. See id. at 1196 .

40. Id.

41. See id. at 1197.

42. A similar understanding of the role of an expert is found in Taylor v. Texas, 939 S.W.2d 148 (Tex. Crim. App. 1996). The Taylor court held that, once a defendant demonstrates that an expert is likely to be a significant factor at trial, the defendant is entitled to the services of this expert. See id. at 152. The court describes the expert's role as first, providing the tools to challenge the state's case, and second, testifying at trial if the expert's opinion supports the defense theory. Id. at 153.

43. Id. 
Most state courts have understood the role of a DNA expert to be quite different from the role described by the Polk and Dubose courts. These courts have relied on the Caldwell Court's requirement that a defendant demonstrate a reasonable need for the requested expert services to reject defense requests for expert assistance in a DNA case. ${ }^{44}$ By rejecting such requests as unreasonable, these courts do not even reach the Mathews balancing test. Instead, they imply that a defendant's need for expert DNA assistance is not significant enough to make the request reasonable. An examination of how these courts have characterized the rejected defense requests for assistance and of what these courts have suggested the defense would need to assert to satisfy this threshold requirement of reasonableness reveals that these courts assume that defense DNA experts do not play a necessary role in criminal trials.

Almost any explanation of why a particular defendant needs assistance in a DNA case can be characterized as either a need for someone to educate the defense attorney or as a need for someone who can competently investigate, analyze, and present independent conclusions to a jury. For example, the following request can be understood either way:

The assistance of a DNA expert is crucial to the defendant in this case. DNA printing is a highly complex process which only a trained expert fully understands. Without this understanding, defense counsel cannot properly prepare for trial, or understand appropriate avenues to question results or cross-examine experts testifying for the prosecution. Without special training, the defense counsel would be at the mercy of the prosecutor's expert, unable to discern weaknesses in the procedures used or in the interpretation of the results. ${ }^{45}$

That a court rejected this request because the defense attorney's memorandum revealed a basic understanding of DNA technology ${ }^{46}$ strongly suggests that the court understood this statement as a request for education only, and not one for an expert who would actively contribute to the search for truth. Similarly, other courts have characterized a request for assistance as no more than a plea that DNA evidence is

44. See, e.g., Cade v. Florida, 658 So. 2d 550, 554-55 (Fla. Dist. Ct. App. 1995); Michigan v. Leonard, 224 Mich. App. 569 (1997); Coleman v. Mississippi, 697 So. 2d 777 (Miss. 1997); North Carolina v. Mills, 420 S.E.2d 114, 118-19 (N.C. 1992); Tennessee v. Edwards, 868 S.W.2d 682, 697 98 (Tenn. Crim. App. 1993), Husske v. Virginia, 476 S.E.2d 920 (Va. 1996); see also Norton v. Texas, 930 S.W.2d 101 (Tex. App. 1996); Taylor v. Texas, 939 S.W.2d 148 (Tex. Crim. App. 1996).

45. Tennessee v. Edwards, 868 S.W.2d 682, 697-98 (Tenn. Crim. App. 1993).

46. The court noted that the memorandum filed by the defense attorney

contain[ed] an extensive discussion of DNA technology, including a citation of authorities and the extent to which mathematical probabilities are available for both whites and blacks. The defendant provided as an example one instance of a defendant improperly convicted based upon DNA identification testimony; the identification later proved to be erroneous. Id. at 698 . 
simply too "complicated"47 and as no more than an argument that DNA testing is a novel process that can only be understood by a qualified expert. ${ }^{48}$ By choosing to characterize these requests as a need for information and not investigation, these courts implicitly accept a specific conception of the role that a DNA expert would play in a criminal case. Even the Dubose opinion reflects this understanding when the court suggests that an expert is useful because defense attorneys are generally unable to understand DNA evidence..$^{9}$

The conception of the DNA expert as no more than a source of information also underlies these courts' discussions of what a defense attorney might be able to plead in order to satisfy the Caldwell standard. These courts have stated that they are looking for a more "developed"so request, or a statement of need that establishes a "particularized necessity" for a DNA expert. ${ }^{51}$ Presumably, these courts would grant a request demonstrating that a DNA expert will perform the same role as a psychiatrist by investigating, interpreting, and testifying. By rejecting requests for an expert on the ground that the defendant has not made such a showing, the opinions of these courts suggest that they are convinced a DNA expert could act only as a passive instructor, not as an active participant at trial.

The role of a defense expert described in the Polk and Dubose opinions stands at odds with the role articulated by these other courts. The resolution of these conflicting understandings and the corresponding evaluation of the need inherent to a request for an expert will have significant implications for any inquiry into the states' obligations under the Constitution.

\section{The Certainty of the Science}

Perhaps the most significant factor behind the varied results of state court decisions concerning requests for assistance in DNA cases is a disagreement concerning the level of certainty of DNA test results. The one state court that explicitly held there is no right to state-funded DNA experts did so precisely because, in its view, DNA technology is not subject to a wide range of possible outcomes. ${ }^{52}$ Other decisions,

47. Cade, 658 So. $2 \mathrm{~d}$ at 555 .

48. See, e.g., Mills, 420 S.E.2d at 118-19: Taylor v. Texas, 939 S.W.2d at 151 (quoting the prosecution's characterization of the defendant's request: "The thrust of [defense] counsel's argument concerned his desire to have an expert educate him regarding DNA evidence so that he could rebut the state's case on cross examination. Defense counsel's expressed need to be tutored in the field of DNA falls short of establishing a specific need for expert assistance.").

49. See, e.g., Dubose v. Alabama, 662 So. 2d 1189, 1196 (Ala. 1995).

50. Cade v. Florida, 658 So. 2d 550, 554 (Fla. Dist. Ct. App. 1995) (quoting Moore v. Kemp, 809 F.2d 702, 712 (11 th Cir. 1987))

51. Tennessee v. Edwards, 868 S.W.2d 682, 698 (Tenn. Crim. App. 1993).

52. See Harrison v. Indiana, 644 N.E.2d 1243, 1253 (Ind. 1995). 
however, suggest that the ambiguities and differences of opinion that affect the scientific analysis of any DNA sample are significant enough to justify awarding defendants the funds needed to hire expert assistance. $^{53}$

According to the Supreme Court of Indiana, DNA is a precise science that leads to singular results. In Harrison $v$. Indiana, ${ }^{54}$ the court turned to Indiana case law for the proper test to determine whether or not a defendant is entitled to expert services. ${ }^{55}$ In a case where the defense seeks expert assistance, one of the factors Indiana courts consider is whether the evaluation process involves precise, physical measurements and chemical testing. If so, according to the Indiana court, expert services can be of little use to a defendant, and a trial court may therefore refuse the defendant's request for funds to hire an expert to rebut the state's evidence.

Where the testimony of the experts involved "precise, physical measurements and chemical testing, and there is no showing that these experts were less than precise or able in their testing and observations, that the truth or accuracy of their testimony is questionable by some new evidence, or that there is evidence available or likely from other experts which would indicate that they are wrong," the trial court did not abuse its discretion in denying a motion for appointment of an expert. ${ }^{56}$

Applying this rule to its analysis of DNA evidence, the Harrison court held that there is no state constitutional right to receive the assistance of a DNA expert. This conclusion compelled the court to distinguish Ake. It did so by observing that

[p]sychiatry is an extremely uncertain field dealing with the mysteries of the human mind where expert opinions can be expected to and do differ widely. In contrast, the neutral [DNA] experts here were testifying to the results of a test "involving precise, physical measurements and chemical testing." Under these circumstances, the trial court did not abuse its discretion by denying appointment of defendant's requested expert. ${ }^{57}$

No case has considered directly the precision involved in interpreting DNA evidence and reached a conclusion opposite to the one reached by the Harrison court. An accurate determination of the certainty of DNA science will necessarily affect the inquiry into the states' obligations under the Constitution. If DNA technology is as certain as

53. See, e.g., Husske v. Virginia, 448 S.E.2d 331, 335-40 (Va. Ct. App. 1994), superseded on reh'g en banc, 462 S.E.2d 120 (Va. Ct. App. 1995), aff'd 476 S.E.2d 920 (Va. 1996).

54. 644 N.E.2d 1243 (Ind. 1995).

55. See id. at 1252-53.

56. Id. at 1253 (quoting Schultz v. Indiana, 497 N.E.2d 531, 534 (Ind. 1986)).

57. Id. (quoting James v. Indiana, 613 N.E.2d 15, 21 (Ind. 1993) (citations omitted)). 
the Harrison court suggests, an expert will be of little use to a defendant. However, if DNA technology is subject to significant uncertainties, then Ake supports a finding that due process requires defense access to DNA experts in any criminal case in which DNA evidence is an issue.

\section{II}

\section{The LIMITS OF DNA TESTING}

In order to resolve the dispute between courts over the role of a DNA expert and the extent to which DNA technology is a certain science, it is necessary to examine carefully the nature and limits of DNA testing in general. Of course, opinions differ concerning the accuracy of DNA tests. Some experts assert that DNA evidence is "fail-safe," that any error in the testing will always benefit the defense, ${ }^{59}$ or that it is impossible to obtain a false positive result. ${ }^{60}$ Others argue that, even though DNA testing involves some ambiguity, the defense bar has exaggerated the utility of an independent expert. ${ }^{61}$

More careful analysis of DNA testing does not support these views. $^{62}$ In reality, a wide variety of problems can affect the use of DNA

58. Colorado v. Fishback, 829 P.2d 489, 492 (Colo. Ct. App. 1991), aff'd 851 P.2d 884 (Colo. 1993).

59. See Rockne P. Harmon, General Admissibility Considerations for DNA Typing Evidence: Let's Learn from the Past and Let the Scientists Decide This Time Around, in ForENSIC DNA TECHNology 169 \& n.104 (Mark A. Farley \& James J. Harrington, eds. 1991) ("[E]ven if the technology itself were capable of producing an incorrect result, it is highly improbable that the result would be an incorrect identification of an innocent person. It is significantly more likely that an error will erroneously exclude the truly guilty party.").

60. See Cobey v. Maryland, 559 A.2d 391, 392 (Md. Ct. Spec. App. 1989) (citing Andrews v. Florida, 533 So. 2d 841 (Fla. Dist. Ct. App. 1988) (noting that an incorrect match is an "impossible" result)).

61. See, e.g., Andre A. Moenssens, DNA Evidence and Its Critics-How Valid Are the Challenges, 31 JuRIMETrics J. 87, 107 (1990) (suggesting that the literature identifying problems surrounding DNA testing should be discounted because it is not subject to peer review and its authors are underqualified).

62. See generally Jonathan J. Koehler, DNA Matches and Statistics: Iniportant Questions, Surprising Answers, 76 JudicAture 222 (1993) [hereinafter Koehler, DNA Matches]; Jonathan J. Koehler, Error and Exaggeration in the Presentation of DNA Evidence at Trial, 34 JURIMETRICs J. 21 (1993) [hereinafter Koehler, Error and Exaggeration]; Eric S. Lander, DNA Fingerprinting on Trial, 339 Nature 501 (1989); Peter J. Neufeld \& Neville Colman, When Science Takes the Witness Stand, 262 SCI. AM. 46 (1990); William C. Thompson, Subjective Interpretation, Laboratory Error and the Value of Forensic DNA Evidence: Three Case Studies, 96 GenETICA 153 (1995); William C. Thompson \& Simon Ford, The Meaning of a Match: Sources of Ambiguity in the Interpretation of DNA Prints, in Forensic DNA TechNologY, supra note 59 at 93, 138.

The National Research Council has strongly challenged the notion that the results of DNA testing are infallible:

DNA evidence is not infallible; all laboratory work is subject to error; and, given current population data banks and laboratory protocols, a witness or prosecutor will seldom (if ever) be justified in stating that the probability that a reported DNA match involves someone other than the suspect is so low as to make that possibility implausible. Claims that treat DNA identifications as though they are as reliable as fingerprint identification in the 
technology in a criminal trial. RFLP testing is one method of comparing DNA from an unknown source with DNA from a known source. ${ }^{63}$ To effect this comparison, forensic laboratories break down the DNA strands by adding a digestive enzyme that separates the molecule at known locations. The fragments are then placed in a gel and separated by electrophoresis. The resulting pattern of separation is magnified and recorded on an x-ray film, called an autoradiograph or an autoradiogram (an "autorad" for short). This film allows the scientist to measure the lengths of specific strands and to compare these lengths with the lengths of the same strands in another sample. If the lengths are the same, a match is declared, and population statistics are used to evaluate the significance of the match. ${ }^{64}$

The validity and reliability of the general process used to create an autorad have been established for quite some time now. ${ }^{65}$ Even during the great admissibility debates of recent years, other issues, such as the validity of statistical analyses, and not the underlying process have been the main subjects of contention. Nonetheless, several different problems may corrupt the process in any given case. For example, an individual lab might use an enzyme other than those used by most labs and, therefore, be subject to criticism for not using a sufficiently established and accepted protocol. ${ }^{66}$ Similarly, it is always possible that a lab that employs an established protocol may not follow it in a specific case. ${ }^{67}$ Also, random factors such as enzyme failure or abnormal salt concentrations may cloud the results of a test. ${ }^{68}$

typical rape or murder case are unjustified; until technology and databanks improve, they

are likely to remain so.

See NRC REPORT, supra note 1 , at 161 .

63. Summary descriptions of the RFLP process are abundant. See NRC REPORT, supra note 1, at 36-40; Koehler, DNA Matches, supra note 62, at 223-24; McKenna et al., supra note 9, at $281-84$.

64. For a more complete discussion of the factors that go into declaring a match, see infra notes $76-96$.

65. See Office of Technology Assessment, U.S. Congress, Genetic Witness: Forensic USES OF DNA TESTS 59 (1990) ("[N]o scientific doubt exists that technologies available today accurately detect genetic differences."); McKenna et. al., supra note 9, at 285 ("The basic laboratory procedures used in RFLP analysis have been used in non-forensic settings for many years and are generally accepted by molecular biologists.").

66. See, e.g., California v. Marlow, 41 Cal. Rptr. 2 d 5 (Ct. App. 1995) (holding that because the enzyme used by the prosecution's lab was not the same enzyme employed by the FB1 labs, the results of the DNA test were inadmissible because they were not generated by a generally accepted process).

67. Even ardent advocates of the reliability of DNA evidence concede that failure to follow protocol may be a problem in a given case. See, e.g., Moenssens, supra note 61, at 107 "'Whether the experts, in a particular case, have followed the proper protocols with respect to standard analytical procedures remains an issue that the defense bar has a duty to explore.").

68. See Koehler, Error and Exaggeration, supra note 62, at 23 (quoting from the testimony of Dr. Robert Kidd, presented in California v. Axell, 1 Cal. Rptr. 2 d 411 (Ct. App. 1991)). 
Beyond these more case-specific problems, a variety of difficulties may affect each stage of a DNA test. This potential for multiple kinds of error provides defendants with several questions they might raise about the validity or weight of the evidence confronting them. A review of these potential problems will enable a more accurate assessment of the certainty of DNA technology and the role an expert might play in a criminal trial.

\section{A. False Positives and Cross-Contamination}

In any case of DNA testing, there is a possibility that the samples being compared have been contaminated, switched, or mixed at some point of the handling or testing process:

DNA from one sample may inadvertently be mixed with another sample at a number of stages: when the samples are collected, during DNA extraction procedures, when enzymes and buffers are added to samples for restriction digestion, or when samples are placed in the well of the gel (due to failure to use a fresh micropipet tip, spillage, or inaccurate sample placement) ${ }^{69}$

Although it may be true that some sorts of testing errors will result only in a falsely negative result, a false positive is clearly possible if tested samples are mislabeled, confused, or contaminated in a busy crime lab. When such sample mix-ups occur, the resulting autorads will indicate a match between DNA taken from a crime scene and DNA obtained from a suspect. In reality, however, they demonstrate nothing more than a match between two samples of the suspect's own DNA. ${ }^{70}$

There have been very few blind, external proficiency tests of DNA labs that could enable an accurate prediction of the real chances of cross-contamination. ${ }^{71}$ Instead, many DNA labs conduct their own tests, the results of which are not published. ${ }^{72}$ Even where external tests have been conducted, it is not clear whether the false positives discovered by these tests result from cross-contamination or from other interpretive

69. Thompson \& Ford, supra note 62, at 111; see also NRC REPORT II, supra note 3, at 80-84; NRC REPORT, supra note 1 at $65-67$.

70. For a clear example of a false positive created by cross-contamination between samples at Cellmark, see Thompson \& Ford, supra note 62, at 111-15 (documenting one instance of crosscontamination that was brought to light in a proficiency test performed by the California Association of Crime Laboratory Directors ("CALCLD")). Although Cellmark claimed to have taken steps that would reduce the likelihood of such errors in the future, a second CACLD test revealed another false positive caused by cross-contamination. See Thompson, supra note 62, at 155 .

71. At least three such tests have been conducted, two by CACLD and another by Collaborative Testing Services. See Koehler, Error and Exaggeration, supra note 62, at 23 n.3, 24 nn.11 \& 13.

72. See id. at 24-25 ("Surprisingly, there have been no blind external proficiency tests conducted to date."). 
and reporting errors. ${ }^{73}$ Similarly, there has been debate over the meaning of these external tests' findings. For example, some interpret the results of two tests performed by the California Association of Crime Laboratory Directors ("CACLD") as showing that Cellmark Diagnostics has a false positive rate of 1 in $1255 . .^{74}$ Others, using the same data, have argued that Cellmark's false positive rate is around 5.5 percent. $^{75}$ Still others have suggested that these past tests cannot accurately predict Cellmark's current rate of error. ${ }^{76}$ In any case, the fact that false positives have occurred in blind proficiency tests clearly demonstrates the possibility that similar problems may affect the test results in any given criminal case. ${ }^{77}$

\section{B. Ambiguities in Testing Data}

Even in the absence of cross-contamination or similar problems, declaring a match is not as straightforward as it may seem. After the autorads are created, the lab technician conducting the test must compare the positions of the recorded DNA fragments. If two samples of DNA produce a pattern of segments located in identical positions on the autorad, then the two samples are declared a match. ${ }^{78}$ Some experts suggest that declaring such a match is a straightforward, objective evaluation. They argue that autorads "are as clear as supermarket bar codes, that each autorad is unique, and that the fragment pattern (print) on the autorad containing DNA from one individual is readily and absolutely distinguishable from all others."79 However, many different problems can affect the declaration of a match, and autorads often contain ambiguous information.

One common form of ambiguity is called "slop." Slop has been defined as the "inevitable variability in the appearance of DNA prints caused by minor variations in procedures, reagents, samples, and the like." 80 Professor William Thompson suggests that slop is often present in the results of RFLP tests and argues that only the subjective judgment

73. Koehler, for example, argues that, even though the Collaborative Testing Services report listed no false positives, there were at least three incidents in which the lab reported a match, even though the autorad did not support the report. See id. at 25.

74. See B. Devlin et al., Comments on the Statistical Aspects of the NRC's Report on DNA Typing, 39 J. FORENSIC SCI. 28, 37 (1994).

75. See Thompson, supra note 62, at 155; see also Koehler, Error and Exaggeration, supra note 62. at 25-26 ("Taken together, all these results suggest that false positive errors occur in one to four percent of match reports provided in open proficiency tests.").

76. See NRC REPORT II, supra note 3, at 86.

77. See Thompson \& Ford, supra note 62 , at 114 (noting two such cases).

78. See NRC REPORT, supra note 1, at 53-54.

79. Thompson \& Ford, supra note 62 , at 94 n.8.

80. Id. at 94 n.6. 
of the DNA analyst can resolve the resulting ambiguities. ${ }^{81}$ Thompson lists several potential sources of such ambiguity: band shift, in which banding patterns in two different lanes appear to be similar, but are displaced up or down relative to each other; extra bands, where two DNA patterns match but for the presence in one lane of at least one band that is not present in the other; missing bands, where a suspect's sample matches a known sample but is missing one or more bands; and faint or smeary bands. ${ }^{82}$ Whenever one or more of these ambiguities are present, the person comparing two autorads must use his or her subjective judgment either to dismiss the ambiguities as unimportant or to attach some significance to them.

Although there are many legitimate reasons why this sort of ambiguity may cloud the results of a test, it is never possible to rule out true genetic difference as the explanation. When, for example, bands appear within one sample but not within an otherwise matching sample, this difference could be attributed to true genetic differences, to sample degradation, to contamination, or to any other number of factors. ${ }^{83}$ Because there are multiple possible explanations for these ambiguities, a person comparing two samples affected by such problems must employ subjective judgment to select an explanation for the ambiguity.

As an example of how ambiguities might affect actual casework, Thompson discusses a 1993 case in which some, but not all, of the autorads showed a band in the samples from the defendant that was not present in any of the evidentiary samples. ${ }^{84}$ The presence of this extra band resulted in three different interpretations by the experts who reviewed the evidence:

One expert, a professor at a major medical school who has expertise in DNA biochemistry and extensive experience with RFLP analysis, concluded that the extra band was exculpatory, indicating that the discrepancy on probe G3 would, in his judgment, be "very, very unlikely" if the samples were from the same source. A second expert, who is a professor of biology at a major university and has expertise in molecular genetics, and who has testified as an expert for both the prosecution and defense in cases involving DNA evidence, found the extra band troubling but not fully exculpatory.... A third interpretation of the extra band is found in the laboratory report, which states: "One additional band was observed in the DNA banding

81. See William C. Thompson, Evaluating the Admissibility of New Genetic Identification Tests: Lessons from the "DNA War," 84 J. CRIM. L. \& CRIminology 22 (1993); Thompson, supra note 62, at 153; William C. Thompson \& Simon Ford, DNA Typing: Acceptance and Weight of the New Genetic Identification Tests, 75 VA. L. REv. 45 (1989); Thompson \& Ford, stupra note 62, at 93.

82. See Thompson \& Ford, supra note 62, at $94-95$.

83. See id. at 110-37.

84. See Thompson, supra note 62 , at $159-61$. 
pattern of [the suspect]. The origin of this band has not been determined, but does not affect the ability to interpret the results." 85

The danger in cases like this-when multiple interpretations of an autorad are possible-is that "an analyst will mistakenly attribute true genetic differences between samples to the slop effects."86. The fact that many laboratories do not conduct DNA testing blindly enhances this possibility. The DNA analysts are often in close contact with prosecutors and other law enforcement personnel. ${ }^{87}$ Thompson tells of a confrontation he had with a forensic analyst who defended his declaration of a match despite the presence of some ambiguities in the testing by saying, "I must be right, they found the victim's purse in [the defendant's] apartment." Because of such contact between forensic labs and other law-enforcement investigators, information external to the test itself may well influence the subjective judgments necessitated by ambiguities in test results. ${ }^{89}$ This possibility of bootstrapping could result in a false positive or an unequivocal declaration of a match despite serious problems with such a declaration.

Thompson's discussion of the 1989 case of Mississippi v. Parker provides another example of how ambiguities might significantly impact a criminal case..$^{90}$ In Parker, a forensic laboratory declared a match between a DNA sample obtained during the investigation of a rape and murder and the DNA sample obtained from defendant Parker. ${ }^{91}$ The report of this match did not indicate any ambiguities. When an independent expert reviewed the autorads in question, however, he observed several extra bands that matched neither the suspect nor the victim. Because the lab report did not mention these bands at all, the person conducting the test must have discounted them as insignificant artifacts.

Based upon the appearance and location of the bands, the defense expert suggested that DNA from a third person was present in the sample. In fact, subsequent testing revealed a match between these extra bands and the DNA pattern of another individual, referred to by Thompson as MM. ${ }^{92}$ The discovery of this match was particularly important to the Parker case because Parker had argued that MM had perpetrated the crimes in question. When considered in conjunction with

85. Id. at $160-61$.

86. Thompson \& Ford, supra note 62 , at 95.

87. See Thompson, supra note 62 , at 154 .

88. Id.

89. See NRC REPORT II, supra note 3, at 84-85 (noting the possibility of bias and suggesting that independent review by a defense expert is one of the strongest available means of detecting and eliminating such bias).

90. See Thompson \& Ford, supra note 62, at 117-19.

91. See Thompson, supra note 62 , at 156.

92. See id. at $\mathbf{1 5 9 .}$ 
the possibility of cross-contamination, it is quite plausible that MM did commit the crimes, and that the presence of Parker's DNA in the evidentiary sample was the product of human error.

As with false positives, it is not clear how often ambiguities will affect the use of DNA testing in a criminal case. Many experts suggest that ambiguities occur frequently. Fourteen of twenty cases reviewed by Thompson and Ford revealed at least one kind of ambiguity and often several together. ${ }^{93}$ Because most lab work is not subject to random, external review, it is difficult to say whether this is representative of the rate at which such problems affect actual case work. Simon Ford, a professional DNA consultant, estimates that problems serious enough to raise questions about the evidence arise in five to ten percent of the cases he has seen..$^{94}$ Similarly, Thompson suggests that ten percent may be a reasonably accurate estimate of the number of cases affected by ambiguities. ${ }^{95}$ Another expert estimates that ambiguities in autorads raise questions in roughly one out of every four cases. ${ }^{96}$

\section{Exaggerations of the Significance of a Match}

After declaring a match, a forensic scientist will attempt to establish its significance by determining how frequently one would expect the tested combination of genetic traits to appear randomly in members of the population at large. In the early 1990s, the validity of this process became the subject of heated debate within the scientific community. ${ }^{97}$ The National Research Council ("NRC") subsequently suggested a set of standards designed to avoid some of the recognized problems. ${ }^{98}$ It appears that these suggestions have more or less resolved the debate. Most scientists now agree that when the importance of a match is

93. See Thompson \& Ford, supra note 62 , at 139 tbl. 1.

94. See Telephone Interview with Simon Ford (Mar. 27, 1996). While he is careful to note that these figures are rough estimates, Ford breaks down his estimate of the frequency with which ambiguities affect the use of DNA technology in a legal action into three categories of problems. In the first category are problems Ford describes as "loose ends"--they may affect weight but are not likely to be pivotal in a criminal case. Examples of these loose ends include unreported extra bands and separation problems. He suggests that questions concerning these sorts of problems can be raised in about fifty percent of the cases he sees. In another category are radical problems that might mean the evidence really shows an exculpatory pattern instead of the incriminating pattern identified by a crime lab. This sort of problem, according to Ford, arises in only a handful of cases. In between these two categories are fairly serious problems-like a failure to address mixed samples or a lab report that analyzes only one of the patterns in an autorad. It is this last sort of problem, something between loose ends and radical problems, that Ford claims is present in five to ten percent of the cases he sees.

95. See Thompson, supra note 9.

96. See Electronic Mail Message from Dan Krane, Professor, Department of Biological Sciences, Wright State University, Dayton Ohio (Mar. 11, 1996). Professor Krane notes, however, that his sample is relatively small. To date, he has been involved in about fifteen cases. See id.

97. See Lander \& Budowle, supra note 5, at 735.

98. See NRC REPORT, supra note 1. 
calculated according to the statistical methods recommended by the NRC, it is possible to obtain a reasonably accurate appreciation of the significance of a declared match. ${ }^{99}$ Even where the NRC methods are followed, however, there may still be several grounds for questioning the statistical report in any given case.

One of the most important potential problems with the statistics used by the prosecution is that they may not adequately account for all of the factors that have gone into the declaration of a match. For example, where ambiguities affect the declaration of a match, those ambiguities should be accounted for in calculating that match's significance. ${ }^{100}$ In the Parker case, for example, the prosecution's expert testified that the DNA pattern in question should appear at random in only one of 30 billion samples. ${ }^{101}$ Accounting both for the likelihood that the second bands truly were artifacts and for the potential for crosscontamination and lab error, however, Thompson argues that a more accurate likelihood ratio of a similar banding pattern occurring at random drops to about one in $9,000 .{ }^{102}$ While this is still an impressive statistic, it is much less incriminating than the one-in-30-billion ratio suggested by the prosecution's expert. If we refuse to assume that the extra bands are artifacts, which may be reasonable in light of the circumstances of the case, the significance of the match is even lower, possibly as low as one in ten. ${ }^{103}$

Similarly, any statistical conclusion about the significance of a match must also account for case-specific problems with the application of general population statistics. For example, in a case in which more than one of the suspects are related, the possibility that they will have matching or similar DNA patterns increases dramatically. In such a case, it may be inappropriate to use general population statistics to prove that one of these suspects (and not the other) is the source of the sample in question. ${ }^{104} \mathrm{~A}$ similar problem may occur in cases in which the precise number of DNA donors is unknown. If, for example, evidence is gathered after a woman is raped by more than one man, it will be necessary to make important assumptions about the source of the DNA

99. See Lander \& Budowle, supra note 5, at 735.

100. See Thompson, supra note 62, at 167. But see NRC REPORT II, supra note 3, at 85-87 (arguing that to combine the probability of laboratory error with the probability of a random match is "ill-advised" in light of the difficulties of ascertaining error rates. It is an arguably different thing, however, to include the effects of known and accomodated ambiguities within the statistical assessment of a particular match than it is to combine uncertain lab error rates with the statistical evaluation of every match.).

101. See Thompson, supra note 62 at 158-59.

102. See id.

103. See id. at 159.

104. See NRC REPORT II, supra note 3 at 6 , recommendation 4.4 . 
samples. ${ }^{105}$ Whenever problems like this one are involved in declaring a match, it will be important for the defense to argue that the statistical significance of the match is less than it would be if assumptions regarding the source of the sample were unnecessary.

It is also all too easy to misstate the meaning of the statistical analysis of the significance of a match and thereby allow (if not encourage) a jury to make improper inferences about the significance of a match. Jonathan Koehler has argued not only that this is a frequent problem, ${ }^{106}$ but also that it is often overlooked by defense attorneys, sometimes resulting in "findings against defendants who would have been successful at trial if the evidence had been presented properly."107 Koehler documents several different ways in which the importance of the statistical significance of a match has been exaggerated or misrepresented at criminal trials. First, there is a tendency to confuse the frequency with which a banding pattern appears in the population at random with the literal probability that someone other than the defendant is the source of the evidentiary sample. ${ }^{108}$ For example, when an FBI scientist was questioned by a prosecuting attorney in Wike $v$. Florida, ${ }^{109}$ he responded as follows:

Q: So the blood on the blanket can you say that it came from Sayeh Rivazfar [the victim]?

A: With great certainty I can say that those two DNA samples match and they are identical. And with population statistics we can derive a probability of it being anyone other than that victim.

Q: What is that probability in this case?

105. See id. at $129-30,162-63$ (suggesting techniques to be used where a sample includes DNA from multiple donors).

106. See Koehler, Error and Exaggeration, supra note 62, at 22; see also Dan Krane, supra note 96 ("I have yet to review a report that did not misrepresent the significance of a match to at least some degree-always in favor of the prosecution and usually in regard to the reported population statistics.").

107. Koehler, DNA Matches, supra note 62, at 223.

108. Koehler provides examples from cases around the country: "The FB1 ... calculated that there was one chance in 300 million that the DNA from the semen sample could have come from someone in the caucasian population other than Jakobetz." Koehler, Error and Exaggeration, supra note 62, at $28 \mathrm{n} .24$ (quoting United States v. Jakobetz, $955 \mathrm{~F} 2 \mathrm{~d}$. 786, 789 (2d Cir. 1992)). "[T] hat the frequency of that DNA banding pattern in the Hispanic population is approximately 1 in 6 billion... meant that the chance that anyone else but appellant left the unknown hairs at the scene of the crime is 6 billion to 1." Id. (quoting California v. Axell, 1 Cal. Rptr. 2d 411, 415 (Cal. Ct. App. 1991)). "[T]he suspect's DNA is compared to information in Cellmark's African-American data base to determine the probability of an African-American other than the defendant leaving the semen stain on the bed sheet. Foreman testified the probability was $I$ in $300,000 . "$ Id. (quoting lllinois v. Miles, 577 N.E.2d 477 (Ill. Ct. App. 1991)). "The statistical probability that the semen came from another white male was 1 in 13.5 million." Id. (quoting Kelly v. Texas, 729 S.W.2d 579, 582 (Tex. Crim. App. 1990)).

109. 596 So. 2 d 1020 (Fla. 1992). 
A: In this case that probability is that it is one in 7 million chances that it could be anyone other than the victim. ${ }^{110}$

Although the difference between this description and an accurate explanation of the importance of the DNA population statistics may ap- . pear to be a question of semantics, the difference is significant. If the jury is told, as it should be, that the frequency ratio reported by a geneticist is only the chance that the discovered genetic characteristics would appear in the population at random, the jury could conclude that someone other than the defendant (or the victim in Wike) was the source of the sample. To reach this conclusion, a jury would only need to accept that the DNA from this other person coincidentally shared the tested characteristics. On the other hand, when the expert tells the jury that the number represents the chances of anyone other than the defendant having left a sample at the crime scene, it is almost impossible (if the jury believes the testimony) for it to make a finding that the defendant was not the source of the DNA sample. This is especially true when an expert is willing to testify that he is certain that the tested trace came from a particular person. ${ }^{111}$

Other ways that the statistical significance of a match has been exaggerated at trial include testimony that the frequency with which genetic traits will appear in the population at random is the same as the probability that any two people will share the same pattern of DNA, ${ }^{12}$ and that it represents the number of people who would need to be tested before a particular pattern was found. ${ }^{113}$ Whenever such testimony is presented in a criminal case, it is both misleading and dangerous in that it encourages the fact-finder to give DNA evidence more weight than it is due.

III

\section{OF ROLES AND UNCERTAINTY}

In light of the foregoing discussion of the false positives, ambiguities, and exaggerations that can effect a DNA test at any of several stages, it should now be possible to resolve some of the confusion state courts have demonstrated over the role an expert may play in a criminal trial and over the certainty of DNA science.

110. Koehler, Error and Exaggeration, supra note 62, at 29 (quoting the transcript of the trial court proceeding in Wike).

111. See e.g., Washington v. Cauthron, 846 P.2d 502, 515-16 (Wash. 1993) (expert tcstificd that the defendant "is the source of the semen sample in the five cases that we got the result on" and that the DNA could not have come from anyone else on earth).

112. See Koehler, Error and Exaggeration, supra note 62, at 33.

113. See id. at 34 . 


\section{A. The Role of a DNA Expert}

There are many ways an independent DNA expert could be of value to a defendant in a criminal case. More than simply educating a defense attorney about some complex and highly technical processes, a DNA expert can examine the laboratory's report, including the protocol employed, the autorads, and the declared statistical importance of a match. At each of these stages the expert can identify false positives, ambiguities, and exaggerations and can determine whether retesting is necessary, whether the prosecution's interpretation of the DNA evidence is correct, and whether the prosecution's evidence is as strong as the prosecution claims it to be.

A DNA expert, aware of the possibility of false positives and knowledgeable about the potential sources of this kind of error, will recognize signals such as extra or missing bands, band shift, or other problems that suggest the possibility of cross-contamination, sample switching, or handling errors. If any of these signals are present, the expert could suggest a controlled retesting to rule out the possibility that true genetic difference does not account for the problems identified. Even when a match contains no clues that cross-contamination has occurred, an expert would still be able to still remind the defense attorney of the possibility of cross-contamination or handling errors that exists in every case. ${ }^{114}$ Furthermore, if the prosecution relies on DNA evidence alone, or if other evidence contradicts the inferences the DNA evidence generates, the expert could at least demonstrate how the possibility of a false positive raises significant doubts about the prosecution's case.

A DNA expert could also identify any ambiguities that may have gone undetected or unreported in the declaration of a match. When ambiguities are present in a set of autorads, a defense expert can recognize the ambiguities and identify how subjective judgments have affected the declaration of a match. As in the Parker case, ${ }^{115}$ a DNA expert working for the defense might be able to articulate alternative theories to explain the presence of extra bands that the lab discounted, or the presence of band shift and margin-of-error judgments in measuring..$^{116}$

In the last stages of DNA testing, a defense expert will recognize instances of exaggeration in the determination and characterization of the statistical significance of a declared match. An expert will also be able to ensure that the prosecution's laboratory has applied accepted

114. See supra notes $69-77$ and accompanying text.

115. See supra notes $90-92$ and accompanying text.

116. See, e.g., supra note 85 and accompanying text (discussing case in which three experts disagreed over whether an extra band on an autorad was exculpatory, bothersome but not exculpatory, or irrelevant). 
statistical principles to the evaluation of a match. If a declared match is subject to some ambiguities, the expert could suggest how these ambiguities might be accounted for in the determination of its significance. Similarly, a defense expert could identify cases in which typical population statistics are inappropriate because of problems created by factors like related suspects, who share many genetic characteristics, or suspects of an unknown race, where it is not certain which population sub-group should be used as a frequency marker. ${ }^{117}$

Finally, when DNA evidence is presented to a jury, an expert could recognize whether statistical evidence is presented in a misleading way. For example, an expert could recognize as misleading a statement that statistics reflect the likelihood that someone other than the defendant is the source of a forensic sample, or that they establish unequivocally that the defendant is the source of the sample. Then, the expert could testify to explain the importance of a match in clear terms that a jury can understand.

In short, a DNA expert would play a significant role in identifying the false positives, ambiguities, and exaggerations that may affect the forensic use of DNA fingerprinting technology. At each stage of the testing process, the DNA expert can review the work a laboratory has performed for the prosecution. In reviewing protocols, lab notes, autorads, reports, statistical calculations, and courtroom testimony, the DNA expert can identify potential sources of error, provide alternative interpretations of data generated by the prosecution, propose new tests that might be useful in a criminal case, and present the results of this review in an understandable manner to the trier of fact.

\section{B. Parallels to Psychiatry}

The role of a DNA expert parallels that of a psychiatrist as summarized by the Ake Court. Just as psychiatrists "gather facts, through professional examination[s] [and] interviews," 118 DNA experts gather facts by reviewing the results of a scientific test and the procedure used to achieve these results. It is true that the DNA expert does not necessarily perform a new test on the physical evidence, which might seem to be the equivalent of the psychiatrist's examination or interview. The psychiatrist's examination, however, is only a means of obtaining data that is then explained in light of some theory about the human psyche. A DNA expert obtains data by reviewing an autorad. Just as the psychiatrist, the DNA expert then explains this data in light of available theories about genetic mapping-by ascertaining the presence and positions of bands on an autorad and attaching significance to these positions based

117. See NRC REPORT II, supra note 3, at 113-16.

118. Ake v. Oklahoma, 470 U.S. 68,80 (1985). 
upon the expert's knowledge, skills, and experience. That the DNA expert did not create the autorad itself is not important. In observing the number, position, and density of bands on an autorad, the DNA expert studies a subject in the same way a psychiatric expert does-both must interpret what they see and apply some set of theoretical concepts to these observations to reach some conclusion concerning their observations.

Moreover, the DNA expert's role at trial parallels that of a psychiatrist. Just like psychiatric experts, DNA experts know "the probative questions to ask of the opposing party's psychiatrist." "19 They can translate a technical finding into "language that will assist the trier of fact." 120 In the absence of either a psychiatrist or a DNA expert, the prosecution could present as certain the conclusion of one expert. Without the benefit of the alternative interpretation of a defense expert, the jury cannot accurately evaluate the evidence.

\section{The Certainty of the Science}

Some still might argue that DNA evidence differs from psychiatric evidence because it is derived from a precise science that obtains certain and accurate results. ${ }^{121}$ As the Ake Court emphasized, psychiatry is not an exact science:

$[\mathrm{P}]$ sychiatrists disagree widely and frequently on what constitutes mental illness, on the appropriate diagnosis to be attached to given behavior and symptoms, on cure and treatment, and on likelihood of future dangerousness.... [T] gle, accurate psychiatric conclusion on legal insanity in a given case. ${ }^{122}$

Because of the perception that DNA evidence leads to a single, accurate conclusion (match or no match), it might be tempting to believe that DNA evidence does not create a similar risk of erroneous resolution in a criminal trial.

As the previous Section establishes, however, uncertainty affects every stage of the DNA testing process to some degree. Because there is always a chance that samples have been mislabeled or contaminated, one can never be certain that a test really compares the specimens that need to be compared in order to draw valid inferences about a defendant's guilt. Similarly, every determination that two samples match might be subject to a variety of uncertainties and ambiguities. When a state court

119. Id.

120. Id.

121. See, e.g., Harrison v. Indiana, 644 N.E.2d I243, 1253 (Ind. 1995) (finding that DNA tests involve "neutral" experts and "precise, physical measurements and chemical testing").

122. Ake, 470 U.S. at 81. 
rejects a request for a DNA expert on the grounds that DNA is an exact science that involves precise physical measurements, it does so only by overlooking these sources of potential problems.

Of course, problems will not be identified in every case in which DNA evidence is presented. This does not mean, however, that DNA is a certain science. Due process does not guarantee the assistance of psychiatric experts because there will be a difference of psychiatric opinion in every case. Instead, the Ake Court found that defendants have a right to have an independent expert conduct an examination and "help determine whether the insanity defense is viable." 123 There will inevitably be some cases in which the expert for the defense reviews the conclusions of the state's psychiatrists and is unable to find fault with them. That problems might not be found in all cases does not mean that either psychiatry or DNA technology is certain. Instead, the possibility that two experts will reach different conclusions concerning the results of a DNA test establishes that DNA, like psychiatry, is an uncertain science. The frequency of such conflicting conclusions is not as important as the genuine possibility thereof in any case.

\section{IV \\ Due Process Reconsidered}

Defense requests for state-funded assistance in a criminal case in which the prosecution presents DNA evidence are likely to take two forms. First, a defendant may want to have an independent expert review the prosecution's evidence. Second, a defendant may want to retest the DNA samples from which the prosecution derives its evidence. These two resources, an independent expert and a second round of tests, would allow a defendant confronted with DNA evidence to expose almost all of the potential problems involved with such evidence. However, these two requests involve different costs and benefits. Accordingly, a state's constitutional obligation regarding a defendant's request will depend upon just what form of assistance he seeks.

\section{A. Caldwell's Requirement of Reasonableness}

\section{The Request For an Expert}

A state court confronted with a request for a DNA expert must first decide whether the defendant has adequately demonstrated that the requested expert will be useful to the presentation of a defense. ${ }^{124}$ At this stage, some courts require a defense attorney to identify specific problems with a DNA test before considering whether due process requires

123. Id. at 82 (emphasis added).

124. See supra notes $29-31$ and accompanying text. 
the appointment of an expert in a particular case. The Edwards decision, for example, requires a defendant to show a "particularized necessity" for a DNA expert. ${ }^{125}$ Although the meaning of this phrase is not entirely clear, the court apparently wants the defense attorney to identify the grounds upon which the defense can challenge the prosecution's evidence. By suggesting that the Caldwell requirement can only be met with a specific showing of what is wrong with the prosecution's evidence, these courts demonstrate that they have accepted an inaccurate and misleading understanding of the role of a DNA expert and of the ability of defense attomeys to articulate their need for expert assistance.

Unless a defense attorney is trained in the sciences that underlie the process of DNA identification, that attorney will never be as capable as a DNA expert at spotting potential problems. ${ }^{126}$ Most defense attorneys cannot even explain what kinds of problems an expert might look for or how an expert could ensure that the use of DNA evidence is relatively free from these uncertainties. Although it may be possible to train defense attorneys to recognize some of the more blatant instances of testing error, ${ }^{127}$ it is unreasonable to expect that most attorneys could ever detect the subtle problems that can affect the results of any given test.

Courts should not require defendants to identify specific errors that have affected a DNA test prior to determining whether they should grant a defendant the funds to hire an expert to address these specific problems. Given the potential for uncertainty in every DNA test, courts should presume that Caldwell's requisite showing of need is met whenever the prosecution proffers evidence derived from DNA technology. Because there is always a significant possibility that DNA evidence is clouded by one or more of the problems identified above, every defendant confronted with such evidence has a reasonable need for the assistance of an independent DNA expert who, unlike the defendant's attorney, has the ability to recognize these problems.

\section{The Request for Another Test}

Although a presumption of reasonableness should accompany every defense request for an expert to review the prosecution's DNA evidence, this same presumption does not hold true when a defendant asks the court for funds to retest DNA evidence. Retesting can detect only an extremely limited set of problems, such as spillage, inaccurate

125. Tennessee v. Edwards, 868 S.W.2d 682, 698 (Tenn. Crim. App. 1993).

126. For a more developed analysis of a defense attorney's inability to effectively address the limitations inherent to DNA fingerprinting, see infra Part IV.D.1.

127. See, e.g., Richard A. Nakashima, DNA Evidence in Criminal Trials: A Defense Attorney's Primer, 74 NEB. L. REv. 444 (1995) (attempting to explain to defense attorneys how to defend a DNA case). 
sample placement, or mislabeling of the test itself. For example, in the case of a false match like the one identified in the CACLD test ${ }^{128}$ apparently caused by cross-contamination in the laboratory-retesting might result in no match where the prosecution's expert initially declared one. However, this limited sort of false positive occurs very infrequently. The most skeptical assessments suggest that this kind of false positive occurs in less than two percent of DNA tests. ${ }^{29}$

If retesting were the only, or even an effective, means of rectifying these infrequent problems, a request for retesting would be reasonable in every case. However, retesting will usually do nothing to expose the most common problems affecting a DNA test, such as a subjective interpretation of ambiguities or the exaggeration of the significance of a match. These problems can only be identified by a review of the data generated and presented by the prosecution. Retesting also will not be useful in detecting such errors as contamination at the crime scene or mislabeled samples. By the time forensic evidence is subjected to DNA testing, it may actually be impossible to detect this kind of error because any subsequent tests will be performed on the same samples, presumably with the same result. This sort of error can only be brought to light through evidence of the actual sample switch or crime-scene contamination. By insisting on a retest, the defendant may actually be overlooking other means of attacking the DNA evidence, such as questioning the chain-of-custody testimony or the prosecution's protocol for collecting samples.

Even if a second series of tests results in a declaration that the samples do not match, the defendant's problems are not over. In such a case, the prosecution would most likely demand a third test to resolve the conflicting results. If this test results in another positive, for whatever reason, then a fourth test would be needed. At some point, the sample will be consumed, and the prosecutor may elect to rely on the first positive test, arguing that lab error or some other problem caused the subsequent negative result obtained by the defendant. The factfinder may or may not find reasonable doubt in the fact that a second test produced negative results. This possibility, combined with the fact that most of the problems and ambiguities of RFLP testing surface after a test has been completed and not during the creation of an autorad, strongly limit the utility of retesting an evidentiary sample.

Without more, a request for funds to perform a retest on the prosecution's evidence is not reasonable. While no published opinion has specifically considered such a request, a court could rely on Caldwell in such a case and hold that, by itself, a request for retesting

128. See supra note 70 and accompanying text.

129. See supra notes 71-77 and accompanying text. 
does not demonstrate utility to a defendant sufficient to satisfy the Caldwell requirement of reasonableness. Courts should approach the question of retesting with a rebuttable presumption that it is not necessary to the defense of a DNA case. This presumption could be overcome by evidence that some specific kind of testing error occurred in the first test. For example, an expert might demonstrate that the presence of an extra band in a control lane suggests crosscontamination instead of artifact. Until the defendant comes forward with such evidence, however, he has probably not met the Caldwell Court's requirement that a request be reasonable. It is important to note, however, that this analysis of a request for retesting depends upon the understanding that a state must ${ }^{130}$ provide a defense expert who, as part of the more general role that expert plays, can accurately assess the utility of retesting in a specific case.

At this first stage of the due process analysis, then, a court should usually find it necessary to apply the Mathews test to any request for a DNA expert but not to every request for a second series of tests. The various problems that potentially affect every case of DNA testing create a need for an expert great enough to satisfy Caldwell's requirement of reasonableness. By contrast, because only a limited set of problems can be detected through a retest, and because the appropriateness of retesting can only be accurately identified by an expert who has reviewed the prosecution's evidence, it is probably not reasonable for the defendant automatically to receive funds to retest the evidence in every case. In any case, once a court gets beyond this initial question of reasonableness, it must then apply the Mathews balancing test to determine whether due process requires the court to provide the requested services.

\section{B. The Private Interest}

Unlike the other elements of the Mathews analysis, the private interest involved in both the request for an expert and the request for a second test is the same: Any defendant in a criminal DNA case stands to be deprived of life or liberty if the state overcomes the presumption of innocence. Although this is true in any criminal case, DNA evidence is a very powerful means of establishing guilt. Members of a jury may perceive DNA evidence as particularly persuasive. ${ }^{131}$ Because DNA

130. See infra Part IV.E (discussing due process).

131. Because no behavioral research concerning the impact of DNA evidence on members of a jury has been performed, any assertion concerning juror perceptions of DNA evidence is, at best, a guess. See NRC ReporT II, supra note 3, at 203-204. This said, it is possible that the O.J. Simpson trial has rendered some people skeptical of the power of DNA to persuade a jury. However, because of Simpson's celebrity status and the media frenzy surrounding the trial, the Simpson case probably should not be understood as a typical criminal trial. More importantly, it should be remembered that Simpson was able to hire several DNA experts to examine, retest, and testify on his 
evidence derives from the scientific analysis of physical samples, factors that cloud testimony from lay witnesses, such as problems with perception, memory, and narrative, are not readily apparent in evidence concerning the results of a DNA test. In the absence of these kinds of problems, jurors may perceive DNA evidence as more reliable or convincing than other forms of evidence. The high numbers involved in the statistical analyses of a match may also provide jurors with the certainty they need to discount any doubts that exist concerning other evidence presented in a trial.

Given the possibility that a jury will find DNA evidence particularly persuasive, the private interest in a request for retesting or an expert should weigh heavily in our analysis. As with a criminal case involving the defense of insanity, the individual interest of a criminal defendant confronted with evidence derived from DNA fingerprinting technology is "almost uniquely compelling." 132 As in Ake, "The interest of the individual in the outcome of the State's effort to overcome the presumption of innocence is obvious and [should] weigh[] heavily in our analysis." 133

\section{The State's Interest}

\section{The Request For an Expert}

In contrast to the individual's compelling interest in defending his innocence, the state has a minimal interest in not providing funds to hire a DNA expert. The state's interest is essentially identical to the interest identified in Ake. As the Court observed there, the state's interest in prevailing in a criminal trial is necessarily tempered by its interest in fairness and accuracy. ${ }^{134}$ Because of this interest in fairness, the state has no conceivable interest in a criminal case other than the financial burden involved in providing an indigent defendant with a defense expert. In Ake, the Court did suggest that some expert services could create a financial burden great enough to justify denying the requested funds. ${ }^{135}$ However, the Court held that providing a single, competent psychiatric expert does not create such a burden. ${ }^{136}$ The question, then, is whether providing a single DNA expert to indigent defendants in criminal cases would be so much more costly than providing a psychiatric expert that the burden on the state justifies withholding these funds.

behalf. Therefore, that trial should be seen as demonstrating the benefits of having an independent expert examine the prosecution's DNA evidence, and not as demonstrating the inability of DNA evidence, on its own, to persuade a jury.

132. Ake v. Oklahoma, 470 U.S. 68, 78 (1985).

133. Id.

134. See id. at 79.

135. See id.

136. See id. at 84 . 
Based on an informal survey of DNA experts, the going rate for their services is about $\$ 150$ an hour. ${ }^{137}$ Of course, the number of hours needed to evaluate the evidence vary from case to case. In every case, however, the expert will need at least to review the laboratory reports, the autorads, the lab's protocol, and the statistical calculations. This original assessment usually takes between four and six hours. ${ }^{138}$ If this evaluation does not reveal any of the errors discussed above, it might take another few hours to consult with the defense attorney, explain the possibilities of a false positive caused by cross-contamination or switched samples, point out how to avoid misrepresentation of the statistics in court, and answer any questions that the attorney may have. ${ }^{139}$ If, however, the initial examination does turn up problems with the evidence, the expert would need to spend more time with the case, perhaps researching explanations for the problems, testifying at trial, assisting in the presentation of these problems to the trier of fact, or crossexamining the prosecution's witnesses. These activities would increase the time an expert would spend, and therefore increase the costs to the

137. This survey consisted of a conversation with William Thompson and a series of electronic mail communications will Professor Thompson, Dan Krane, Peter Donnelly, a phone conversation with Simon Ford, one with employees of Cellmark Diagnostics of Germantown, Maryland, and a review of Cellmark's published fee schedule. Cellmark charges $\$ 200 /$ hour to review autorads generated by outside labs and to consult with defense attorneys. If they perform a full series of tests, however, there is apparently no charge for telephone consultations. They have fixed rates for most of their other services. See Cellmark Diagnostics, Forensics Fee Schedule (on file with the author). All of these people have testified in the past and have contact with other experts who provide their services to defense attorneys.

In addition to experts available for hire, there are, apparently, some experts who will review DNA evidence at no charge. (Although Dan Krane does not accept compensation, his employer asks that he be compensated $\$ 100$ per hour for time spent away from his normal duties.) Because there are some volunteers out there, it might be possible to argue that defense attorneys can obtain experts at no cost, but because the issue here is obtaining state funding for experts, it is more important to ask how much it would cost if the defendant is unable to find someone to look over the evidence pro bono.

138. See Thompson, supra note 9 (estimating that a thorough review would take about four hours); Krane, supra note 96 (estimating that "[a] thorough review of autorads can usually be accomplished in less than an hour .... Lab reports can generally be reviewed in approximately two hours. Since lab protocols rarely change from one review to another, they can be reviewed in lcss than two hours."). Cellmark personnel suggest that, even though it is difficuit to identify an average number of hours spent, in a simple case with three or four pieces of evidence it might take about two or three hours to review the autorads and casework, and another hour to review the lab's protocol. See Telephone Interview with Cellmark employees (March 26, 1996). Simon Ford, who was also careful to note the tentative nature of such estimates, reports that it will usually take him less than two hours to review the autorads in a simple case where he is already familiar with the laboratory's protocol and proficiency. See Ford, supra note 94.

139. Because the amount of time needed to consult with the defense attomey will vary with every case, and largely depends upon the experience, curiosity, and satiability of the defense attorney, it is difficult to estimate the cost of an expert. Cellmark employees suggest that this consultation will take anywhere from half an hour to many hours. See Cellmark Interview, supra note 138. Simon Ford, on the other hand, suggests that consultation in the average case will take between four and six hours. See Ford, supra note 94. 
state. Dan Krane reports that his participation in a typical case will cost $\$ 1,200$ plus travel expenses. ${ }^{140}$ Cellmark laboratories charges $\$ 1,100$ to $\$ 1,200$ plus expenses for each day of testimony by one of its experts. ${ }^{141}$ The total cost of providing a DNA expert, ${ }^{142}$ then, will range anywhere from a few hundred dollars in most cases to a few thousand in those cases where significant involvement is necessary.

These costs are surprisingly similar to the expenses of employing a psychiatric expert. Psychiatric experts charge anywhere from $\$ 100$ $\$ 150$ per hour for their testing and research services. ${ }^{143}$ If further services are needed, many experts charge a flat fee of $\$ 1,000$ to $\$ 1,500$ per day spent traveling and testifying in a case involving an insanity defense. ${ }^{144}$ The amount of time billed for each case will depend upon the circumstances. It has been suggested that eight hours can serve as a rough estimate of the amount of time required to prepare for a trial, ${ }^{145}$ but even the most minimal of services, spending 15 to 60 minutes with a defendant to determine whether or not they are competent to stand trial, will cost the state about $\$ 300 .^{146}$ As with DNA experts, the exact costs of providing psychiatric experts will vary from case to case. However, the costs of both services are substantially similar; costs of basic pretrial screening are minimal, but the costs of testifying, researching further problems, and otherwise participating in the presentation of the defendant's case may be substantial. Based upon this comparison, there is no reason to believe that the costs of providing a DNA expert are significantly more burdensome than the costs of providing psychiatric services.

\section{The Request for Another Test}

The state's interest in not providing funds to perform a second series of tests in every DNA case is arguably greater than it is not providing a defense expert to review the prosecution's evidence. The financial costs of RFLP testing alone may be insubstantial: a RFLP test

140. See Krane, supra note 96.

141. See Cellmark Diagnostics, supra note 137.

142. This does not include the costs of any additional testing that an expert might need to perform. See id. for an estimate of these costs.

143. See Paul Zisla, Psychiatric Assistance for Indigent Defendants Pleading Insanity: The Michigan Experience, 20 J. LEGAL REFORM 907, 933 n. 174 (1987).

144. See id.

145. See id. at 933.

146. See Pamela Casey \& Ingo Keilitz, An Evaluation of Mental Health Expert Assistance Provided to Indigent Criminal Defendants: Organization, Administration, and Fiscal Management, 34 N.Y.L. ScH. L. REv. 19, 67 (1989) (studying the financial costs of implementing Ake, and documenting that the city of Baltimore pays $\$ 295$ each time a defendant is screened for competency to stand trial). 
costs about $\$ 550 /$ sample. $^{147}$ However, the costs of a retest must be added to the other costs of hiring an expert. Also, once the state has paid for a defense expert to review and to retest the DNA evidence, the state will also have to pay for the prosecution's expert to review the results of this test. Because of this layering of costs, the total cost of retesting the DNA evidence may be substantially greater than the cost of providing a single psychiatric expert. Of course, this increased burden will easily be outweighed if retesting is of great value to the defendant.

\section{The Risk of Erroneous Resolution}

\section{The Request for an Expert}

The most important elements of the Mathews test as applied to a request for a DNA expert are the probable value of the requested assistance and the risk of an erroneous deprivation of the defendant's life or freedom if the state denies the request. The Harrison court believed that DNA evidence is so precise and infallible that there is no real risk of such an erroneous deprivation and an expert is of practically no value to a defendant confronted with DNA evidence. ${ }^{148}$ The Dubose court, by contrast, found that DNA evidence is so powerful that its use must be closely policed. ${ }^{149}$ The most fundamental question we need to resolve, therefore, is whether relying on one DNA expert employed by the prosecution creates a risk of erroneously resolving a factual issue in a criminal trial and, if so, whether providing the defendant with an independent expert will significantly reduce this risk.

Given the uncertainties and ambiguities that can affect any DNA test, relying on one expert does create a significant risk that a jury will misunderstand or inaccurately evaluate the meaning or significance of DNA evidence. The results of a DNA test are presented in stark, blackand-white terms that do not fully reflect the potential problems that can affect any test. A jury is simply told that two samples match and that this match has a certain statistical significance. Even when the declaration of a match results from subjective interpretations of the results of the DNA test, a prosecution expert who has concluded that the two samples do match cannot be relied upon to explain the possible alternative interpretations. Similarly, an expert who exaggerates the significance of a declared match is not likely to explain how this significance is exaggerated.

A DNA expert hired by the state to help the prosecution prepare its case against a criminal defendant might be inclined to overlook the

147. See Cellmark Diagnostics, supra note 137. Cellmark also charges $\$ 550$ per sample to perform PCR testing. If both tests are run on the same sample, the total cost is $\$ 995$ per sample.

148. See supra notes $52-57$ and accompanying text.

149. See supra notes $38-43$ and accompanying text. 
possibility of a false positive, interpret ambiguities in favor of the prosecution, or exaggerate the significance of a match in favor of a defendant's guilt. Although many law enforcement agencies rely on publicly-funded crime labs to process DNA evidence, others rely on private laboratories to perform these tests. These private laboratories, motivated by financial gain and competing with other labs for government contracts, obviously have an incentive to please the law enforcement agencies who hire them. Prosecutors, of course, are pleased when a DNA test confirms a suspect's guilt and when the results of a DNA test are both clear and capable of persuading a jury. Even public crime labs, which may not be subject to the same financial pressures as contract labs, will not be completely free from bias. Many crime labs are in close contact with law enforcement officials. The technicians performing tests for the state are often aware of the circumstances of a case, which may bias them in favor of a particular result. ${ }^{150}$ Given these possible incentives and biases, the uncertainties that may affect any DNA test will go undetected and unresolved if a prosecution expert testifies unchallenged. The result is a great risk that a criminal defendant will be erroneously deprived of his life or liberty.

An expert working for the defense can, in large part, lessen this risk. A defense expert who reviews the prosecution's lab report and autorads can identify the possibility of outright error and recognize cases in which subjective interpretation has clouded the ultimate determination of a match. A DNA expert can provide alternative interpretations of the data generated by the test and determine when outside factors, such as related suspects or multiple donors, affect the statistical significance of a match. In the courtroom itself, an expert familiar with the accurate characterization of the significance of a DNA test can police the presentation of evidence to a jury and ensure that the jurors receive an accurate explanation of the inferences DNA evidence allows them to make. Even if there is a dispute in only ten percent of the cases dealing with DNA evidence, ${ }^{151}$ this policing function can only be fulfilled if defendants have an expert available in all cases. If not, problems will go undetected in one case out of ten. These undetected errors could result in a conviction where the state could not have proven its case beyond a reasonable doubt if the errors had been detected.

Providing an adversarial expert in a DNA case creates a series of safeguards traditionally relied upon by our legal system to test the validity of testimony presented in a criminal case. These safeguards include vigorous cross-examination, the presentation of contrary evidence, and conflicting conceptions of how jury instructions should be

150. See supra notes 87-88 and accompanying text.

151. See supra note $93-95$ and accompanying text. 
framed. ${ }^{152}$ Providing each defendant in a DNA case with an independent expert to review the prosecution's evidence and assist the defendant in presenting the evidence to the jury is the most obvious way of ensuring that these aspects of the adversarial system are effectively present in a DNA case. Even though many have criticized the current system of conflicting expert testimony, ${ }^{153}$ none of these critics would argue for a system in which only one side was allowed to hire and control an expert. As long as the prosecution is allowed to rely on its own DNA experts in criminal cases, the only way to ensure the accuracy of the evidence presented is also to provide the defendant with his own expert. ${ }^{154}$

This analysis raises the question of whether providing a defendant with a DNA expert is the most effective way to address the risk of an inaccurate resolution. One might argue, for example, that any defense attorney can develop enough expertise to effectively cross-examine a DNA expert. ${ }^{155}$ However, because DNA evidence is based upon complex scientific processes, defense attorneys will often be completely unable to address the evidence against their clients. Being untrained in science and unfamiliar with DNA technology, a defense attorney will not know how to question the process that led to the declaration of a match or how to challenge the declared significance of a match. The forensic use of DNA technology derives from several complicated genetic, chemical, and statistical theories. A defense attorney cannot be expected to develop the understanding of the finer points of DNA technology appreciated by professional DNA scientists. Even if it were possible to attain this level of understanding, it is unreasonable to suggest that an attorney, who spends all day researching the law and arguing on behalf of others, will ever be as adept at interpreting autorads as an expert who spends all day doing just that. ${ }^{156}$ Furthermore,

152. See, e.g., Daubert v. Merrell Dow Pharm., Inc., 509 U.S. 579, 596 (1993).

153. See, e.g., Timothy Perrin, Expert Witness Testimony: Back to the Future, 29 U. Rich. L. REv. 1389 (1995) (arguing that the adversarial process is poorly suited to produce accurate expert testimony for a jury); Samuel R. Gross, Expert Evidence, I991 WIS. L. REv. I113 (1991) (criticizing the current use of ordinary expert witnesses).

154. It is possible to conceive of a system in which a single, truly neutral expert is employed by the court instead of by one side or the other. Indeed, the NRC's most recent report on the forensic use of DNA technology suggests that courts may want to hire their own experts. See NRC REPORT II, supra note 3 . Such a system, however, would require an extensive revision of the current one, in which prosecutors enlist DNA labs to work with them to solve cases. Even if it is possible to create a system using truly neutral experts, such a system would lack the adversarial focus of a system in which both sides rely on an expert to police the other side's use of DNA evidence.

155. Tennessee v. Edwards, 868 S.W.2d 682, 698 (Tenn. Crim. App. 1993) (observing that, despite a claimed inability to understand the complexities of DNA evidence, the defense attomey had provided the court with an "extensive discussion of DNA technology, including a citation of authorities and the extent to which mathematical probabilities are available for both whites and blacks.").

156. At Ieast one court has expressly maintained an opposite position. See Michigan v. Leonard, 224 Mich. App. 569 (I997). The Leonard court relied on the facts that the defense attomey had an 
it is unreasonable to expect the defense bar to keep on top of the quickly changing field of genetic testing. Science is not a static field. DNA experts keep abreast of new developments that affect the use of DNA technology in criminal trials. To expect defense attorneys to do the same is unreasonable.

In light of the lack of effective, alternative ways to identify the different problems that might affect the forensic use of DNA fingerprinting technology, and given the uncertainty involved in any DNA test, a DNA expert is indispensable in any criminal case in which the prosecution relies on DNA evidence. Only by providing the defendant with such an expert is it possible to maintain the procedural safeguards upon which we rely to promote fairness and justice in our criminal courts.

\section{The Request for Another Test}

As discussed above, ${ }^{157}$ the limited utility of performing a second series of tests means that, without more, a court probably does not need to consider whether denying such a request might lead to an erroneous deprivation of the private interest involved in a criminal case. However, once a defendant, with the assistance of an independent DNA expert, has articulated exactly how retesting would be useful in a particular case, a court will then need to determine the likelihood that the requested test will lessen an existing risk of inaccurate fact finding. If, for example, a DNA expert identifies a specific problem with the prosecution's test and articulates how retesting will address this problem, then a court might find that performing a second series of tests will diminish the risk of erroneous resolution. The value of retesting, however, can only be determined on a case-by-case basis. Only by considering the specific problems identified by the defense expert and the expert's assessment of whether retesting will resolve these problems can a court accurately identify the risk of an erroneous resolution if it denies retesting.

\section{E. The Balance}

Due process demands that each criminal defendant have access to an independent DNA expert whenever the prosecution seeks to introduce evidence derived from DNA matching technology. A defendant has a significant interest in not being convicted because of the inaccurate use of DNA evidence. Given the incentives built into a system in which one expert, working for the prosecution, presents DNA evidence to a jury, there is a significant risk that this private interest will be

undergraduate degree in chemistry with a minor in biophysics and that he was familiar with the major research publications and cases regarding DNA, to hold that the absence of a real DNA expert did not render the defendant's criminal trial fundamentally unfair. See id. at 585-86.

157. See supra Part IV.A.2. 
wrongfully impaired when the false positives, ambiguities, and exaggerations that can affect the courtroom use of DNA evidence go undetected. The state has a limited financial interest in not providing a DNA expert. The balance of these interests compels the conclusion that there is a constitutional right to receive the assistance of an expert.

A request for funds to retest DNA evidence, however, is not so easily addressed. Unlike the request for an expert, the mere fact that the prosecution seeks to rely on DNA evidence is probably insufficient to justify retesting in every case. Indeed, it is appropriate for any court confronted with a request for retesting to ask the defendant to articulate the potential utility of retesting. Only after a defendant, assisted by an expert, articulates this utility is it even necessary to apply the Mathews test. However, once the defendant articulates a need, if the court is satisfied that retesting is necessary to avoid the risk of an inaccurate resolution of the issues in a case, the value of avoiding this risk will outweigh the state's interest in not providing these funds.

\section{CONCLUSION}

As courts and legislatures become more and more willing to admit DNA evidence in criminal trials, it is important not to confuse admissibility with the propriety of unquestioned use. Instead, the widespread acceptance of DNA technology as a valid forensic tool should increase our concern that it not be misused in the courtroom. We must pause from the rush to admit DNA evidence to ask whether we are properly administering the use of such evidence. One of the most pressing questions in this regard is the one addressed in this Comment-whether criminal defendants are entitled to state-funded assistance in cases in which the prosecution relies on DNA evidence to prove their guilt. In light of the conflicting answers state courts have given to this question, an accurate resolution of this issue is urgent, especially given the stakes involved in a criminal trial and the fundamental importance of fairness in such trials. This Comment, I hope, will take us one step closer to ensuring that fairness is maintained. 
CALIFORNIA LAW REVIEW 